\title{
T-type calcium channel blockers - new and notable
}

\author{
Lubica Lacinová \\ Institute of Molecular Physiology and Genetics, Slovak Academy of Sciences, Bratislava, Slovak Republic
}

\begin{abstract}
Since cloning of the T-type or $\mathrm{Ca}_{\mathrm{V}} 3 . \mathrm{n}$ calcium channel family in 1998-1999 much progress was made in investigation of their regulation. Most effective metal $\mathrm{Ca}_{V} 3$ channel blockers are trivalent cations from lanthanide group together with transition metals $\mathrm{La}^{3+}$ and $\mathrm{Y}^{3+}$. Divalent cations $\mathrm{Zn}^{2+}$, $\mathrm{Cu}^{2+}$ and $\mathrm{Ni}^{2+}$ inhibit $\mathrm{Ca}_{\mathrm{V}} 3.2$ channels more efficiently than $\mathrm{Ca}_{\mathrm{V}} 3.1$ and $\mathrm{Ca}_{\mathrm{V}} 3.3$ channels via second high-affinity binding site including histidine $\mathrm{H} 191$ specific for the $\mathrm{Ca}_{\mathrm{V}} 3.2$ channel. Dihydropyridines and phenylalkylamines in addition to block of L-type calcium channel can inhibit $\mathrm{Ca}_{\mathrm{V}} 3$ channels in clinically relevant concentration.
\end{abstract}

Key words: T-type calcium channels - Dihydropyridines - Phenylakylamines - $\mathrm{Zn}^{2+}, \mathrm{Cu}^{2+}, \mathrm{Ni}^{2+}$, $\mathrm{Co}^{2+}, \mathrm{Cd}^{2+}, \mathrm{La}^{3+}, \mathrm{Er}^{3+}, \mathrm{Y}^{3+}$

T-type or low-voltage-activated or according to the most recent classification $\mathrm{Ca}_{V} 3$ channels (Ertel et al. 2000) are distinguished by their negative voltage threshold for activation, which is between $-70 \mathrm{mV}$ and $-60 \mathrm{mV}$. Such a low activation threshold allows them to participate together with sodium channels in initiation of action potential generation or even generate so-called low threshold action potentials in the absence of sodium channels. Cav3 channels play a role in pathologies including hypertension, heart failure, sleep disorders, epilepsy, drug addiction and neuropathic pain. Currently, three representatives of this channel class are known: $\mathrm{Ca}_{V} 3.1, \mathrm{Ca}_{V} 3.2$ and $\mathrm{Ca}_{V} 3.3 . \mathrm{Ca}_{V} 3.1$ and $\mathrm{Ca}_{V} 3.2$ channels are ubiquitously expressed. The $\mathrm{Ca}_{\mathrm{V}} 3.2$ was found in brain, peripheral nervous tissue (dorsal root ganglion, autonomic ganglia), heart (myocytes, pacemaker cells), smooth muscle, skeletal muscle, bone (osteoblasts), endocrine cells (adrenal, pituitary, pancreas, thyroid) and in sperm. The $\mathrm{Ca}_{\mathrm{V}} 3.1$ was found in all mentioned tissues except for skeletal muscle. Expression of the $\mathrm{Ca}_{\mathrm{V}} 3.3$ channels is restricted to the brain and peripheral nervous tissue (for references see Iftinca and Zamponi 2009).

Detail understanding of mechanisms underlying their regulation may greatly facilitate development of new therapies. Metal ions represent a preferred tool for the mapping of a permeation pathway and for the description of voltage sensor activation. L-type calcium channel blockers dihydro-

Correspondence to: Lubica Lacinová, Institute of Molecular Physiology and Genetics, Slovak Academy of Sciences, Vlárska 5, 83334 Bratislava, Slovak Republic pyridines (DHP) and phenylalkylamines (PAA) are widely used for treatment of cardiovascular diseases therefore their potential ability to regulate T-type calcium channels is of major interest. This review concentrates predominantly on facts reported since the last review (Lacinova 2004).

\section{Metal ions}

\section{Divalent metal cations $\left(M^{2+}\right)$}

Divalent metal cations are commonly known blockers of both high- and low-voltage-activated calcium channels (VACC) lacking high degree of selectivity for a specific VACC class. $\mathrm{Cd}^{2+}$ fully blocks high-VACC in concentrations 5-50 $\mu \mathrm{M}$ ( Fox et al. 1987; Lacampagne et al. 1994; Bleakman et al. 1995). Millimolar concentration of $\mathrm{Co}^{2+}$ is necessary for complete block of high-VACC (Wakamori et al. 1998; Fan and Palade 1999). Compare to high-VACC $\mathrm{Co}^{2+}$ is more effective and $\mathrm{Cd}^{2+}$ less effective in blocking $\mathrm{Ca}_{\mathrm{V}} 3$ channels with $\mathrm{IC}_{50} \mathrm{~s}$ in hundreds of $\mu \mathrm{M}$ (Diaz et al. 2005). $\mathrm{Ca}_{\mathrm{V}} 3.2$ channels are approximately 3 -fold more sensitive than the $\mathrm{Ca}_{V} 3.1$ and $\mathrm{Ca}_{\mathrm{V}} 3.3$ channels (see Table 1). Consistent with an occlusion of the channel's conductive pore the inward currents were strongly blocked while outward current were only moderately affected by $\mathrm{Co}^{2+}$ and $\mathrm{Cd}^{2+}$ (Diaz et al. 2005). Interestingly, $\mathrm{Co}^{2+}$ accelerated tail currents, while $\mathrm{Cd}^{2+}$ slowed those (Diaz et al. 2005). As $\mathrm{Co}^{2+}$ ions have relatively small ionic radius $(0.74 \AA)$ it is possible that $\mathrm{Co}^{2+}$ re-enters the channel pore during repolarization and blocks it. Signifi- 
Table 1. Half-maximal inhibition concentrations $\left(\mathrm{IC}_{50} \mathrm{~s}\right)$ for inhibition of $\mathrm{Ca}_{\mathrm{V}} 3$ channels in mammalian cells by selected agents evaluated at a holding potential $\mathrm{HP}=-100 \mathrm{mV}$, unless noted otherwise

\begin{tabular}{|c|c|c|c|c|}
\hline Agent & $\mathrm{IC}_{50}\left(\mathrm{Ca}_{\mathrm{V}} 3.1\right)$ & $\mathrm{IC}_{50}\left(\mathrm{Ca}_{\mathrm{V}} 3.2\right)$ & $\mathrm{IC}_{50}\left(\mathrm{Ca}_{\mathrm{V}} 3.3\right)$ & in vivo concentration \\
\hline \multirow{2}{*}{$\mathrm{Zn}^{2+}$} & $80 \mu \mathrm{M}^{\mathrm{a}}$ & $0.8 \mu \mathrm{M}^{\mathrm{a}}$ & $160 \mu \mathrm{M}^{\mathrm{a}}$ & $15 \mu \mathrm{M}^{\mathrm{c}}$ (plasma) \\
\hline & $197 \mu \mathrm{M}^{\mathrm{b}}$ & $24 \mu \mathrm{M}^{\mathrm{b}}$ & $152 \mu \mathrm{M}^{\mathrm{b}}$ & $100-150 \mu \mathrm{M}^{\mathrm{c}}$ (brain) \\
\hline \multirow{2}{*}{$\mathrm{Cu}^{2+}$} & \multicolumn{3}{|c|}{$12 \mu \mathrm{M}^{\mathrm{d}}$ (mixture of subtypes) } & $0.1-0.8 \mu \mathrm{M}^{\mathrm{c}}$ (plasma) \\
\hline & - & $0.9 \mu \mathrm{M}^{\mathrm{e}, \mathrm{f}}$ & - & up to $400 \mu \mathrm{M}^{\mathrm{C}}$ (brain) \\
\hline $\mathrm{Ni}^{2+}$ & $250 \mu \mathrm{M}^{\mathrm{g}}$ & $12 \mu \mathrm{M}^{\mathrm{g}}$ & $216 \mu \mathrm{M}^{\mathrm{g}}$ & - \\
\hline $\mathrm{Co}^{2+}$ & $335 \mu \mathrm{M}^{\mathrm{g}}$ & $122 \mu \mathrm{M}^{\mathrm{g}}$ & $345 \mu \mathrm{M}^{\mathrm{g}}$ & - \\
\hline $\mathrm{Cd}^{2+}$ & $128 \mu \mathrm{M}^{\mathrm{g}}$ & $65 \mu \mathrm{M}^{\mathrm{g}}$ & $157 \mu \mathrm{M}^{\mathrm{g}}$ & - \\
\hline isradipine & $<10 \mu \mathrm{M}^{\mathrm{i}}$ & $3 \mu \mathrm{M}^{\mathrm{j}}$ & - & $\sim 50 \mathrm{nM}^{\mathrm{o}}$ \\
\hline nimodipine & $\approx 10 \mu \mathrm{M}^{\mathrm{i}}$ & $6 \mu \mathrm{M}^{\mathrm{j}}$ & - & - \\
\hline nifedipine & $>10 \mu \mathrm{M}^{\mathrm{h}}$ & $21 \mu \mathrm{M}^{\mathrm{j}}$ & - & $\sim 300 \mathrm{nM}^{\mathrm{p}}$ \\
\hline benidipine & - & $140 \mathrm{nM}^{\mathrm{k}}$ & - & - \\
\hline efonidipine & $100 \mathrm{nM}^{\mathrm{l}}(\mathrm{HP}-60 \mathrm{mV}, \mathrm{R}(-))$ & $240 \mathrm{nM}^{\mathrm{k}}$ & - & $20-25 \mathrm{nM}^{\mathrm{r}}$ \\
\hline amlodipine & - & $31 \mu \mathrm{M}^{\mathrm{j}}$ & - & $15 \mathrm{nM}^{\mathrm{s}}$ \\
\hline verapamil & $\begin{array}{c}21 \mu \mathrm{M}^{\mathrm{m}}(\mathrm{HP}-130 \mathrm{mV}) \\
5 \mu \mathrm{M}^{\mathrm{m}}(\mathrm{HP}-70 \mathrm{mV})\end{array}$ & $\geq 50 \mu \mathrm{M}^{\mathrm{n}}$ & - & $250-400 \mathrm{nM}^{\mathrm{t}}$ \\
\hline
\end{tabular}

${ }^{\mathrm{a}}$ Traboulsie et al. 2007, ${ }^{\mathrm{b}}$ Sun et al. 2007, ${ }^{\mathrm{c}}$ Mathie et al. 2006, ${ }^{\mathrm{d}}$ Lu et al. 2009, ${ }^{\mathrm{e}}$ Jeong et al. 2003, ${ }^{\mathrm{f}}$ Nelson et al. 2007a, ${ }^{\mathrm{g}}$ Diaz et al. 2005,

${ }^{\mathrm{h}}$ Lacinova et al. 2000, ${ }^{\mathrm{i}}$ Drigelova et al. 2009, ${ }^{\mathrm{j}}$ Perez-Reyes et al. 2009, ${ }^{\mathrm{k}}$ Inayoshi et al. 2011, ${ }^{\mathrm{l}}$ Furukawa et al. 2004, ${ }^{\mathrm{m}}$ Freeze et al. 2006 ,

${ }^{\mathrm{n}}$ Williams et al. 1999, ${ }^{\mathrm{O}}$ Brown et al. 1986, ${ }^{\mathrm{P}}$ Zhou et al. 1995, ${ }^{\mathrm{r}}$ Saito et al. 1996, ${ }^{\mathrm{s}}$ Watanabe et al. 1996, ${ }^{\mathrm{t}}$ Hoon et al. 1992.

cantly bigger $\mathrm{Cd}^{2+}$ (ionic radius $0.97 \AA$ ) gets trapped inside conductive pore and prevents channel closing.

$\mathrm{Zn}^{2+}, \mathrm{Cu}^{2+}$ and $\mathrm{Ni}^{2+}$ block $\mathrm{Ca}_{\mathrm{V}} 3.1$ and $\mathrm{Cav}_{\mathrm{V}} 3.3$ channels with potency similar to $\mathrm{Co}^{2+}$ and $\mathrm{Cd}^{2+}$ (see Table 1). These three ions are distinguished by $10-20$-fold higher efficiency of $\mathrm{Ca}_{\mathrm{v}} 3.2$ channel inhibition (Table 1). $\mathrm{Zn}^{2+}$ and $\mathrm{Cu}^{2+}$ are nutritional elements with physiological significance. They are present in moderate concentration in human plasma but may occur in high concentration in brain (Mathie et al. 2006; Richelle et al. 2006). Both $\mathrm{Zn}^{2+}$ and $\mathrm{Cu}^{2+}$ are essential divalent cations involved in regulation of several cellular processes including neuronal excitability, synaptic plasticity, gene expression and enzymatic reactions. Zinc blocks VACC in order of efficiency $\mathrm{Ca}_{\mathrm{V}} 1.2>\mathrm{Ca}_{\mathrm{V}} 3.2>\mathrm{Ca}_{\mathrm{V}} 2.3>\mathrm{Ca}_{\mathrm{V}} 2.2$ $=\mathrm{Ca}_{\mathrm{V}} 2.1 \geq \mathbf{C a}_{\mathrm{V}} \mathbf{3 . 3}=\mathbf{C a}_{\mathrm{V}} \mathbf{3 . 1}$ (Sun et al. 2007). Study published along with Sun's report confirmed relative selectivity of $\mathrm{Zn}^{2+}$ ions for $\mathrm{Ca}_{\mathrm{V}} 3.2$ channels compare to $\mathrm{Ca}_{\mathrm{V}} 3.1$ and $\mathrm{Ca}_{\mathrm{V}} 3.3$ channels (Traboulsie et al. 2007). It was explained by Nelson and coauthors (Nelson et al. 2007b) who have shown that $\mathrm{Zn}^{2+}$ constitutively inhibits the $\mathrm{Ca}_{\mathrm{V}} 3.2$ channel via an interaction site involving histidine H191 in extracellular loop connecting IS3-IS4 segments, i.e., within the putative voltage sensor of the channel. $\mathrm{Ca}_{\mathrm{V}} 3.1$ and $\mathrm{Ca}_{\mathrm{V}} 3.3$ channels have a glutamine at corresponding position. Binding pocket for $\mathrm{Zn}^{2+}$ on $\mathrm{Ca}_{\mathrm{V}} 3.2$ channel was further refined by Kang and coauthors that identified D189-G190-H191 in IS3-IS4 loop and D122 in IS2 helix as its main constituents (Kang et al. 2010). As zinc is a common contaminant of experimental solutions this finding has an important implication for experiments on $\mathrm{Ca}_{\mathrm{V}} 3$ channels in general. Inhibition of the $\mathrm{Ca}_{V} 3.2$ channel can be relieved by zinc-chelating agents including L-cysteine, dithiotreitol, bovine serum albumin, diethylenetriaminepentaacetic acid and N,N,N,N'N'tetra-2picolylethylenediamine. Relief of the inhibition lowers the threshold for nociceptor excitability both in vitro and in vivo and represents novel mechanism of nociceptor sensitization (Nelson et al. 2007b). Finding that modulation of the $\mathrm{Ca}_{\mathrm{V}} 3$ channels increased the frequency and the duration of thalamocortical firing (Cataldi et al. 2007; Noh et al. 2010a) implies that endogenous $\mathrm{Zn}^{2+}$ may have a role in controlling thalamocortical oscillations as well.

Binding pocket defined by histidine $\mathrm{H} 191$ underlies also relative selectivity of $\mathrm{Cu}^{2+}$ (Nelson et al. 2007a) and $\mathrm{Ni}^{2+}$ (Kang et al. 2010) for $\mathrm{Ca}_{\mathrm{V}} 3.2$ over $\mathrm{Ca}_{\mathrm{V}} 3.1$ and $\mathrm{Ca}_{\mathrm{V}} 3.3$ channels. This high-affinity site specific to the $\mathrm{Ca}_{\mathrm{V}} 3.2$ channel is located within voltage sensor of the channel domain $\mathrm{I}_{2} \mathrm{Zn}^{2+}$, $\mathrm{Cu}^{2+}$ and $\mathrm{Ni}^{2+}$ inhibit the current via high-affinity site by stabilizing closed state of the channel. This interaction does not alter kinetics or voltage dependence of current activation, inactivation and deactivation.

Interaction with the second low-affinity site located inside the conductive pore modulates the current through $\mathrm{Ca}_{\mathrm{V}} 3.1$ and $\mathrm{Ca}_{\mathrm{V}} 3.3$ channels in a complex manner. Nickel positively shifts voltage dependence of activation and accelerates deactivation of the Cav 3.1 channel (Lacinova et al. 2000). Zinc negatively shifts voltage dependencies of activation and inactivation and slows inactivation kinetics of $\mathrm{Ca}_{\mathrm{V}} 3.1$ and Cav3.3 channels (Traboulsie et al. 2007). Further, it slows 
dramatically deactivation of the $\mathrm{Ca}_{\mathrm{V}} 3.3$ channel (Traboulsie et al. 2007) and moderately slows deactivation of the $\mathrm{Ca}_{V} 3.1$ channel (Noh et al. 2010b). None of these effects was observed on $\mathrm{Ca}_{\mathrm{V}} 3.2$ channels (Traboulsie et al. 2007) most probably because at zinc concentration necessary for their occurrence the channel is already fully blocked via high affinity site located on the voltage sensor.

\section{Trivalent metal cations $\left(M^{3+}\right)$}

Analysis of gating current reflecting activation of voltage sensor of a channel supplies information on basic regulatory mechanisms. Necessary pre-requisition is complete inhibition of ion current by a blocker which blocks the channel conducting pore without affecting movement of voltage sensor of the channel itself. Divalent cations modify kinetics and/or voltage dependencies of activation, inactivation and deactivation of $\mathrm{Ca}_{\mathrm{V}} 3.1$ and $\mathrm{Ca}_{\mathrm{V}} 3.3$ channel (Lacinova et al. 2000; Diaz et al. 2005; Cataldi et al. 2007; Traboulsie et al. 2007; Obejero-Paz et al. 2008; Noh et al. 2010b). Further, $\mathrm{Zn}^{2+}, \mathrm{Cu}^{2+}$ and $\mathrm{Ni}^{2+}$ interact directly with the voltage sensor of the Cav3.2 channel (Kang et al. 2006; Nelson et al. 2007a,b; Kang et al. 2010). Therefore trivalent cations $\mathrm{La}^{3+}$ (Lacinova et al. 2002; Talavera and Nilius 2006) and more recently Er ${ }^{3+}$ (Karmazinova and Lacinova 2010; Karmazinova et al. 2011) were used as $\mathrm{Ca}_{\mathrm{V}} 3$ channel blockers for measurements of gating currents. Trivalent cations from lanthanide group and transition metals $\mathrm{La}^{3+}$ and $\mathrm{Y}^{3+}$ are the most effective cationic blockers of $\mathrm{Ca}_{V} 3$ channels (in order of potency $\mathrm{Y}^{3+}>\mathrm{Er}^{3+}>\mathrm{Gd}^{3+}>\mathrm{Ce}^{3+}>\mathrm{Ho}^{3+}>\mathrm{Yb}^{3+}>\mathrm{Nd}^{3+}>\mathrm{La}^{3+}>$ $\mathrm{Sc}^{3+}$ ) with $\mathrm{IC}_{50}$ in nanomolar region (Mlinar and Enyeart 1993; Beedle et al. 2002). They act solely by entering and occluding the conductive pore of the channel. All currently known features of $\mathrm{Ca}_{\mathrm{V}} 3$ channels inhibition by $\mathrm{M}^{3+}$ can be interpreted in accord with this mechanism:

1) consistent with an open channel block inhibition of inward current amplitude by $\mathrm{M}^{3+}$ was largely voltageindependent within physiological range of membrane depolarizations (Mlinar and Enyeart 1993; Beedle et al. 2002; Obejero-Paz et al. 2004);

2) $\mathrm{M}^{3+}$ did not alter kinetic of inward current trace (Mlinar and Enyeart 1993; Beedle et al. 2002; Lacinova et al. 2002) and such alteration is considered a signature of an inactivated channel's inhibition;

3) inhibitory potency of $\mathrm{M}^{3+}$ decreases when concentration of charge carrier increases (Beedle et al. 2002) suggesting competition for the same binding site inside the conducting pore;

4) inhibitory potency of $\mathrm{M}^{3+}$ decreases when $\mathrm{Ca}^{2+}$ instead of $\mathrm{Ba}^{2+}$ is used as a charge carrier (Beedle et al. 2002) consistent with more effective competition of $\mathrm{Ca}^{2+}$ with $\mathrm{M}^{3+}$ for the same binding site inside the conducting pore;
5) inhibition can be relieved by depolarization to extremely positive voltages (Obejero-Paz et al. 2004) consistent with repulsion of $\mathrm{M}^{3+}$ out of conducting pore;

6) acceleration of tail currents by several $\mathrm{M}^{3+}$ can be explained by rapid re-block of open channels cleared from blocking ion by preceding depolarization (Obejero-Paz et al. 2004);

7) blocking potency of $\mathrm{M}^{3+}$ varied inversely with their ionic radii (Mlinar and Enyeart 1993; Beedle et al. 2002) consistent with more difficult entry of bigger ions into conducting pore.

\section{Dihydropyridines and phenylalkylamines}

DHP were thought to selectively interact with L-type calcium channels (Tsien et al. 1988; Hess 1990; Triggle 2007), however, more recently their interaction with voltage-dependent potassium channels was reported ( Lin et al. 2001; Gao et al. 2005; Caro et al. 2011). They were developed and are still widely used for a treatment of cardiovascular disorders. PAA are clinically used as L-type calcium channels, nevertheless, they interact with potassium ion channels, too (Lefevre et al. 1991; Robe and Grissmer 2000; Rybalchenko et al. 2001).

Initially, T-type calcium channels were described as DHPinsensitive. Nevertheless, during recent years several authors reported block of $\mathrm{Ca}_{\mathrm{V}} 3$ channels by DHPs in micromolar or even nanomolar concentrations (Table 1). Nimodipine and isradipine blocked the $\mathrm{Ca}_{\mathrm{V}} 3.1$ channel with an $\mathrm{IC}_{50}$ below $10 \mu \mathrm{M}$ (Drigelova et al. 2009). This value is more than two decimal orders higher than the $\mathrm{IC}_{50}=16 \mathrm{nM}$ reported for the $\mathrm{Ca}_{\mathrm{V}} 1.2$ channel at a $\mathrm{HP}=-80 \mathrm{mV}$ (Schuster et al. 1996). Furukawa and collaborators (Furukawa et al. 2005) demonstrated that amlodipine, barnidipine, manidipine and nicardipine inhibit with similar efficiency T-type $\left(\mathrm{Ca}_{\mathrm{V}} 3.1\right)$ and L-type $\left(\mathrm{Ca}_{\mathrm{V}} 1.2\right)$ calcium channels expressed in Xenopus oocytes. In the same model, benidipine and efonidipe were even slightly more effective in blocking T-type than L-type calcium channels with $\mathrm{IC}_{50}$ s close to $10 \mu \mathrm{M}$ (Furukawa et al. 2005).

More detailed analysis demonstrated strong voltage- and isomer-dependency of the inhibition of the $\mathrm{Ca}_{V} 3.1$ channel by efonidipine (Furukawa et al. 2004). In mammalian BHK cells $\mathrm{R}(-)$ efonidipine blocked $\mathrm{Ca}_{\mathrm{V}} 3.1$ channels at a holding potential (HP) $-100 \mathrm{mV}$ with an $\mathrm{IC}_{50}$ about $10 \mu \mathrm{M}$ and at a $\mathrm{HP}-60 \mathrm{mV}$ with an $\mathrm{IC}_{50}$ about $0.1 \mu \mathrm{M}$. S(+) enantiomer had similar effect on both channels at both HPs (Furukawa et al. 2004). More effective was efonidipine in inhibition of the $\mathrm{Ca}_{\mathrm{V}} 3.2$ channel in HEK 293 cells with an $\mathrm{IC}_{50}$ of $240 \mathrm{nM}$ at a HP $-90 \mathrm{mV}$ (Inayoshi et al. 2011). Benidipine blocked the $\mathrm{Ca}_{V} 3.2$ channel expressed in HEK 293 cells with an $\mathrm{IC}_{50}$ $140 \mathrm{nM}$ (Inayoshi et al. 2011). (S, S) benidipine was slightly 
better blocker $\left(\mathrm{IC}_{50}=40 \mathrm{nM}\right)$ than $(\mathrm{R}, \mathrm{R})$ benidipine $\left(\mathrm{IC}_{50}\right.$ $=146 \mathrm{nM}$ ) (Inayoshi et al. 2011).

Perez-Reyes and coauthors (Perez-Reyes et al. 2009) analyzed inhibition of the calcium transport through the Cav3.2 channels expressed in HEK 293 cells by variety of DHPs. Efonidipine, felodipine, isradipine and niguldipine appeared to be potent T-type channel blockers with $\mathrm{IC}_{50} \mathrm{~s}<3 \mu \mathrm{M}$ while amlodipine and nifedipine were less efficient with $\mathrm{IC}_{50} \mathrm{~s} 31 \mu \mathrm{M}$ and $21 \mu \mathrm{M}$, respectively (PerezReyes et al. 2009).

The most efficient $\mathrm{Ca}_{\mathrm{V}} 3$ channel blockers efonidipine and benidipine do block also L-type calcium channels. Furukawa and coauthors (Furukawa et al. 2004) called efonidipine selective T-type calcium channel blocker as they found an $\mathrm{IC}_{50}$ for the $\mathrm{Ca}_{\mathrm{V}} 1.2$ channel in millimolar region. However, more recently Tanaka and coauthors (Tanaka et al. 2010) reported the half-maximal inhibitory concentration for the $\mathrm{Ca}_{V} 1.2$ channels around $1 \mu \mathrm{M}$, i.e., comparable with the $\mathrm{IC}_{50}$ for the Cav3.2 channel (Perez-Reyes et al. 2009) and the $\mathrm{Ca}_{V} 3.1$ channel (Furukawa et al. 2004). Further, in mouse ventricular cardiomyocytes efonidipine half-maximal block of both L-type and T-type calcium currents required the same concentration of efonidipine $10 \mu \mathrm{M}$ (Horiba et al. 2008). Even considering that in such preparation identity of individual VACC cannot be equivocally distinguished this finding questions suggested selectivity of efonidipine for T-type calcium channels.

Benidipine seems to be more selective T-type calcium channel blocker as the half-maximal blocking concentration for the Cav1.2 channel was $14 \mu \mathrm{M}$ (Furukawa et al. 1999), i.e., 100-fold higher than the half-maximal inhibitory concentration for the $\mathrm{Ca}_{V} 3.2$ channel (Inayoshi et al. 2011). Still such claim should be taken with certain caution as the former was measured in Xenopus oocytes while the later was measured in mammalian (HEK 293) cell line.

Most commonly used PAA verapamil was previously shown to block T-type calcium channels in smooth muscle cells with an $\mathrm{IC}_{50}=30 \mu \mathrm{M}$ (Kuga et al. 1990) and in spermatogenic cells with an $\mathrm{IC}_{50}=70 \mu \mathrm{M}$ (Arnoult et al. 1998). In mammalian expression system verapamil inhibited the $\mathrm{Ca}_{\mathrm{V}} 3.1$ channel with an $\mathrm{IC}_{50}=21 \mu \mathrm{M}$ at a $\mathrm{HP}$ of $-130 \mathrm{mV}$ and with an $\mathrm{IC}_{50}=5 \mu \mathrm{M}$ at a $\mathrm{HP}$ of -70 $\mathrm{mV}$ (Freeze et al. 2006). The later is close to values 3-8 $\mu \mathrm{M}$ reported for recombinantly expressed $\mathrm{Ca}_{V} 1.2$ channel (Lacinova et al. 1995; Johnson et al. 1996) and for Cav1.2 channel in cardiac myocytes (Wegener and Nawrath 1995). Charged 4-desmethoxyverapamil (D888) blocked the recombinant $\mathrm{Ca}_{\mathrm{V}} 3.1$ with virtually the same efficiency as neutral verapamil with an $\mathrm{IC}_{50}$ less than $20 \mu \mathrm{M}$ (Bergson et al. 2011). D888 is almost thousand-fold more effective L-type calcium channels blocker. An $\mathrm{IC}_{50}$ reported for recombinant $\mathrm{Ca}_{\mathrm{V}} 1.2$ channels is $50 \mathrm{nM}$ (Hockerman et al. 1995; Johnson et al. 1996).

\section{Conclusion}

Block of VACC by metal cations was traditionally viewed as simple physical occlusion of the channel's conducting pore. High affinity interaction with the binding pocket located at extracellular part of the voltage sensor is a novel mechanism. It is notable, that the later does not influence voltage dependence or kinetics of the current while the former may modulate the current kinetics and/or voltage dependence in a complex manner. DHPs and PAAs were widely used in clinical practice as L-type calcium channel blockers. Now it is becoming clear that several of them can block T-type calcium channels at clinically relevant concentrations.

Acknowledgements. Author was supported by the Slovak Research and Development Agency under the contract No. APVV0212-10 and by VEGA 2/0195/10. Author declares no conflict of interest and no financial interest in the publication of this manuscript.

\section{References}

Arnoult C., Villaz M., Florman H. M. (1998): Pharmacological properties of the T-type $\mathrm{Ca}^{2+}$ current of mouse spermatogenic cells. Mol. Pharmacol. 53, 1104-1111

Beedle A. M., Hamid J., Zamponi G. W. (2002): Inhibition of transiently expressed low- and high-voltage-activated calcium channels by trivalent metal cations. J. Membr. Biol. 187, 225-238

http://dx.doi.org/10.1007/s00232-001-0166-2

Bergson P., Lipkind G., Lee S. P., Duban M. E., Hanck D. A. (2011): Verapamil block of T-type calcium channels. Mol. Pharmacol. 79, 411-419 http://dx.doi.org/10.1124/mol.110.069492

Bleakman D., Bowman D., Bath C. P., Brust P. F., Johnson E. C., Deal C. R., Miller R. J., Ellis S. B., Harpold M. M., Hans M., et al. (1995): Characteristics of a human N-type calcium channel expressed in HEK293 cells. Neuropharmacology 34, 753-765 http://dx.doi.org/10.1016/0028-3908(95)00078-K

Brown G. R., Fraser D. G., Castile J. A., Gaudreault P., Platt D. R., Friedman P. A. (1986): Nifedipine serum concentrations following sublingual and oral doses. Int. J. Clin. Pharmacol. Ther. Toxicol. 24, 283-286

Caro A., Tarabova B., Rojo-Ruiz J., Lacinova L. (2011): Nimodipine inhibits AP firing in cultured hippocampal neurons predominantly due to block of voltage-dependent potassium channels. Gen. Physiol. Biophys. 30 (Special Issue), S44-53

Cataldi M., Lariccia V., Marzaioli V., Cavaccini A., Curia G., Viggiano D., Canzoniero L. M., di Renzo G., Avoli M., Annunziato L. (2007): $\mathrm{Zn}^{2+}$ slows down Cav 3.3 gating kinetics: implications for thalamocortical activity. J. Neurophysiol. 98, 2274-2284 http://dx.doi.org/10.1152/jn.00889.2006

Diaz D., Bartolo R., Delgadillo D. M., Higueldo F., Gomora J. C. (2005): Contrasting effects of $\mathrm{Cd}^{2+}$ and $\mathrm{Co}^{2+}$ on the block- 
ing/unblocking of human $\mathrm{Ca}_{\mathrm{v}} 3$ channels. J. Membr. Biol. 207, 91-105 http://dx.doi.org/10.1007/s00232-005-0804-1

Drigelova M., Tarabova B., Duburs G., Lacinova L. (2009): The dihydropyridine analogue cerebrocrast blocks both T-type and L-type calcium currents. Can. J. Physiol. Pharmacol. 87, 923-932 http://dx.doi.org/10.1139/Y09-086

Ertel E. A., Campbell K. P., Harpold M. M., Hofmann F., Mori Y., Perez-Reyes E., Schwartz A., Snutch T. P., Tanabe T., Birnbaumer L., Tsien R. W., Catterall W. A. (2000): Nomenclature of voltage-gated calcium channels. Neuron 25, 533-535 http://dx.doi.org/10.1016/S0896-6273(00)81057-0

Fan J. S., Palade P. (1999): One calcium ion may suffice to open the tetrameric cardiac ryanodine receptor in rat ventricular myocytes. J. Physiol. 516, 769-780 http://dx.doi.org/10.1111/j.1469-7793.1999.0769u.x

Fox A. P., Nowycky M. C., Tsien R. W. (1987): Kinetic and pharmacological properties distinguishing three types of calcium currents in chick sensory neurones. J. Physiol. 394, 149-172

Freeze B. S., McNulty M. M., Hanck D. A. (2006): State-dependent verapamil block of the cloned human $\mathrm{Ca}_{\mathrm{v}} 3.1 \mathrm{~T}$-type $\mathrm{Ca}^{2+}$ channel. Mol. Pharmacol. 70, 718-726 http://dx.doi.org/10.1124/mol.106.023473

Furukawa T., Yamakawa T., Midera T., Sagawa T., Mori Y., Nukada T. (1999): Selectivities of dihydropyridine derivatives in blocking $\mathrm{Ca}^{2+}$ channel subtypes expressed in Xenopus oocytes. J. Pharmacol. Exp. Ther. 291, 464-473

Furukawa T., Miura R., Honda M., Kamiya N., Mori Y., Takeshita S., Isshiki T., Nukada T. (2004): Identification of R(-)-isomer of efonidipine as a selective blocker of T-type $\mathrm{Ca}^{2+}$ channels. Br. J. Pharmacol. 143, 1050-1057 http://dx.doi.org/10.1038/sj.bjp.0705944

Furukawa T., Nukada T., Miura R., Ooga K., Honda M., Watanabe S., Koganesawa S., Isshiki T. (2005): Differential blocking action of dihydropyridine $\mathrm{Ca}^{2+}$ antagonists on a T-type $\mathrm{Ca}^{2+}$ channel (a1G) expressed in Xenopus oocytes. J. Cardiovasc. Pharmacol. 45, 241-246 http://dx.doi.org/10.1097/01.fic.0000154374.88283.15

Gao Z., Sun H., Chiu S. W., Lau C. P., Li G. R. (2005): Effects of diltiazem and nifedipine on transient outward and ultra-rapid delayed rectifier potassium currents in human atrial myocytes. Br. J. Pharmacol. 144, 595-604 http://dx.doi.org/10.1038/sj.bjp.0706113

Hess P. (1990): Calcium channels in vertebrate cells. Annu Rev Neurosci. 13, 337-356 http://dx.doi.org/10.1146/annurev.ne.13.030190.002005

Hockerman G. H., Johnson B. D., Scheuer T., Catterall W. A. (1995): Molecular determinants of high affinity phenylalkylamine block of L-type calcium channels. J. Biol. Chem. 270, 22119-22122 http://dx.doi.org/10.1074/jbc.270.38.22119

Hoon T. J., McCollam P. L., Beckman K. J., Hariman R. J., Bauman J. L. (1992): Impact of food on the pharmacokinetics and electrocardiographic effects of sustained release verapamil in normal subjects. Am. J. Cardiol. 70, 1072-1076 http://dx.doi.org/10.1016/0002-9149(92)90363-4

Horiba M., Muto T., Ueda N., Opthof T., Miwa K., Hojo M., Lee J. K., Kamiya K., Kodama I., Yasui K. (2008): T-type $\mathrm{Ca}^{2+}$ channel blockers prevent cardiac cell hypertrophy through an inhibition of calcineurin-NFAT3 activation as well as L-type $\mathrm{Ca}^{2+}$ channel blockers. Life Sci. 82, 554-560

http://dx.doi.org/10.1016/j.lfs.2007.11.010

Iftinca M. C., Zamponi G. W. (2009): Regulation of neuronal T-type calcium channels. Trends Pharmacol. Sci. 30, 32-40 http://dx.doi.org/10.1016/j.tips.2008.10.004

Inayoshi A., Sugimoto Y., Funahashi J., Takahashi S., Matsubara M., Kusaka H. (2011): Mechanism underlying the block of human $\mathrm{Ca}_{\mathrm{v}} 3.2 \mathrm{~T}$-type $\mathrm{Ca}^{2+}$ channels by benidipine, a dihydropyridine $\mathrm{Ca}^{2+}$ channel blocker. Life Sci. 88, 898-907 http://dx.doi.org/10.1016/j.lfs.2011.03.019

Jeong S. W., Park B. G., Park J. Y., Lee J. W., Lee J. H. (2003): Divalent metals differentially block cloned T-type calcium channels. Neuroreport 14, 1537-1540 http://dx.doi.org/10.1097/00001756-200308060-00028

Johnson B. D., Hockerman G. H., Scheuer T., Catterall W. A. (1996): Distinct effects of mutations in transmembrane segment IVS6 on block of L-type calcium channels by structurally similar phenylalkylamines. Mol. Pharmacol. 50, 1388-1400

Kang H. W., Park J. Y., Jeong S. W., Kim J. A., Moon H. J., PerezReyes E., Lee J. H. (2006): A molecular determinant of nickel inhibition in $\mathrm{Ca}_{\mathrm{v}} 3.2$ T-type calcium channels. J. Biol. Chem. 281, 4823-4830 http://dx.doi.org/10.1074/jbc.M510197200

Kang H. W., Vitko I., Lee S. S., Perez-Reyes E., Lee J. H. (2010): Structural determinants of the high affinity extracellular zinc binding site on $\mathrm{Ca}_{\mathrm{v}} 3.2 \mathrm{~T}$-type calcium channels. J. Biol. Chem. 285, 3271-3281 http://dx.doi.org/10.1074/jbc.M109.067660

Karmazinova M., Baumgart J. P., Perez-Reyes E., Lacinova L. (2011): The voltage dependence of gating currents of the neuronal $\mathrm{Ca}_{\mathrm{v}} 3.3$ channel is determined by the gating brake in the I-II loop. Pflugers Arch. 461, 461-468

http://dx.doi.org/10.1007/s00424-011-0937-2

Karmazinova M., Lacinova L. (2010): Removal of the outermost arginine in IVS4 segment of the $\mathrm{Ca}_{\mathrm{V}} 3.1$ channel affects amplitude but not voltage dependence of gating current. Gen. Physiol. Biophys. 29, 419-423 http://dx.doi.org/10.4149/gpb_2010_04_419

Kuga T., Sadoshima J., Tomoike H., Kanaide H., Akaike N., Nakamura M. (1990): Actions of $\mathrm{Ca}^{2+}$ antagonists on two types of $\mathrm{Ca}^{2+}$ channels in rat aorta smooth muscle cells in primary culture. Circ. Res. 67, 469-480

Lacampagne A., Gannier F., Argibay J., Garnier D., Le Guennec J. Y. (1994): The stretch-activated ion channel blocker gadolinium also blocks L-type calcium channels in isolated ventricular myocytes of the guinea-pig. Biochim. Biophys. Acta 1191, 205-208 http://dx.doi.org/10.1016/0005-2736(94)90250-X

Lacinova L. (2004): Pharmacology of recombinant low-voltage activated calcium channels. Curr. Drug Targets CNS Neurol. Disord. 3, 105-111 http://dx.doi.org/10.2174/1568007043482543

Lacinova L., Klugbauer N., Hofmann F. (2000): Regulation of the calcium channel a1G subunit by divalent cations and organic blockers. Neuropharmacology 39, 1254-1266 http://dx.doi.org/10.1016/S0028-3908(99)00202-6 
Lacinova L., Klugbauer N., Hofmann F. (2002): Gating of the expressed $\mathrm{Ca}_{\mathrm{v}} 3.1$ calcium channel. FEBS Lett. 531, 235-240 http://dx.doi.org/10.1016/S0014-5793(02)03509-3

Lacinova L., Ludwig A., Bosse E., Flockerzi V., Hofmann F. (1995): The block of the expressed L-type calcium channel is modulated by the $\beta 3$ subunit. FEBS Lett. 373, 103-107 http://dx.doi.org/10.1016/0014-5793(95)01013-5

Lefevre I. A., Coulombe A., Coraboeuf E. (1991): The calcium antagonist D600 inhibits calcium-independent transient outward current in isolated rat ventricular myocytes. J Physiol. 432, 65-80

Lin S., Wang Z., Fedida D. (2001): Influence of permeating ions on Kv1.5 channel block by nifedipine. Am. J. Physiol. Heart Circ. Physiol. 280, H1160-1172

Lu L., Wang C., Gao X., Xu P., Wang J., Wang Q., Cheng J., Xiao H. (2009): Effects of copper on T-type $\mathrm{Ca}^{2+}$ channels in mouse spermatogenic cells. J. Membr. Biol. 227, 87-94 http://dx.doi.org/10.1007/s00232-008-9148-y

Mathie A., Sutton G. L., Clarke C. E., Veale E. L. (2006): Zinc and copper: pharmacological probes and endogenous modulators of neuronal excitability. Pharmacol. Ther. 111, 567-583 http://dx.doi.org/10.1016/j.pharmthera.2005.11.004

Mlinar B., Enyeart J. J. (1993): Block of current through T-type calcium channels by trivalent metal cations and nickel in neural rat and human cells. J. Physiol. 469, 639-652

Nelson M. T., Joksovic P. M., Su P., Kang H. W., Van Deusen A., Baumgart J. P., David L. S., Snutch T. P., Barrett P. Q., Lee J. H., Zorumski C. F., Perez-Reyes E., Todorovic S. M. (2007a): Molecular mechanisms of subtype-specific inhibition of neuronal T-type calcium channels by ascorbate. J. Neurosci. 27, $12577-12583$ http://dx.doi.org/10.1523/JNEUROSCI.2206-07.2007

Nelson M. T., Woo J., Kang H. W., Vitko I., Barrett P. Q., Perez-Reyes E., Lee J. H., Shin H. S., Todorovic S. M. (2007b): Reducing agents sensitize $\mathrm{C}$-type nociceptors by relieving high-affinity zinc inhibition of T-type calcium channels. J. Neurosci. 27, $8250-8260$ http://dx.doi.org/10.1523/JNEUROSCI.1800-07.2007

Noh J., Choi H. J., Chung J. M. (2010a): $\mathrm{Zn}^{2+}$ enhances the intrinsic bursting activity of a rat thalamic relay neuron. Neurosci. Res. 67, 95-97 http://dx.doi.org/10.1016/j.neures.2010.01.008

Noh J., Kim M. K., Chung J. M. (2010b): A novel mechanism of zinc block on a1G-like low-threshold T-type $\mathrm{Ca}^{2+}$ channels in a rat thalamic relay neuron. Neurosci. Res. 66, 353-358 http://dx.doi.org/10.1016/j.neures.2009.12.005

Obejero-Paz C. A., Gray I. P., Jones S. W. (2004): $\mathrm{Y}^{3+}$ block demonstrates an intracellular activation gate for the a $1 \mathrm{G} \mathrm{T}$-type $\mathrm{Ca}^{2+}$ channel. J. Gen. Physiol. 124, 631-640 http://dx.doi.org/10.1085/jgp.200409167

Obejero-Paz C. A., Gray I. P., Jones S. W. (2008): $\mathrm{Ni}^{2+}$ block of Cay 3.1 (a1G) T-type calcium channels. J. Gen. Physiol. 132, 239-250 http://dx.doi.org/10.1085/jgp.200809988

Perez-Reyes E., Van Deusen A. L., Vitko I. (2009): Molecular pharmacology of human $\mathrm{Ca}_{\mathrm{v}} 3.2 \mathrm{~T}$-type $\mathrm{Ca}^{2+}$ channels: block by antihypertensives, antiarrhythmics, and their analogs. J. Pharmacol. Exp. Ther. 328, 621-627 http://dx.doi.org/10.1124/jpet.108.145672
Richelle M., Sabatier M., Steiling H., Williamson G. (2006): Skin bioavailability of dietary vitamin E, carotenoids, polyphenols, vitamin C, zinc and selenium. Br. J. Nutr. 96, 227-238 http://dx.doi.org/10.1079/BJN20061817

Robe R. J., Grissmer S. (2000): Block of the lymphocyte $\mathrm{K}^{+}$channel mKv1.3 by the phenylalkylamine verapamil: kinetic aspects of block and disruption of accumulation of block by a single point mutation. Br J Pharmacol. 131, 1275-1284 http://dx.doi.org/10.1038/sj.bjp.0703723

Rybalchenko V., Prevarskaya N., Van Coppenolle F., Legrand G., Lemonnier L., Le Bourhis X., Skryma R. (2001): Verapamil inhibits proliferation of LNCaP human prostate cancer cells influencing $\mathrm{K}^{+}$channel gating. Mol. Pharmacol. 59, 1376-1387

Saito T., Fujii K., Takizawa T., Toyosaki T., Kuwabara Y., Kobayashi S., Ichikawa H., Karaki A., Yamazaki Y., Iwata J., Yamada K., Tomiya H., Takeda K., Inagaki Y. (1996): Effects of the new calcium antagonist efonidipine hydrochloride on resting and exercise hemodynamics in patients with stable effort angina. Arzneimittelforschung 46, 861-867

Schuster A., Lacinova L., Klugbauer N., Ito H., Birnbaumer L., Hofmann F. (1996): The IVS6 segment of the L-type calcium channel is critical for the action of dihydropyridines and phenylalkylamines. Embo. J. 15, 2365-2370

Sun H. S., Hui K., Lee D. W., Feng Z. P. (2007): $\mathrm{Zn}^{2+}$ sensitivity of high- and low-voltage activated calcium channels. Biophys. J. 93, 1175-1183 http://dx.doi.org/10.1529/biophysj.106.103333

Talavera K., Nilius B. (2006): Evidence for common structural determinants of activation and inactivation in T-type $\mathrm{Ca}^{2+}$ channels. Pflugers Arch. 453, 189-201 http://dx.doi.org/10.1007/s00424-006-0129-7

Tanaka H., Namekata I., Ogawa T., Tsuneoka Y., Komikado C., Takahara A., Iida-Tanaka N., Izumi-Nakaseko H., Tsuru H., AdachiAkahane S. (2010): Effects of S(+)-efonidipine on the rabbit sinus node action potential and calcium channel subunits $\mathrm{Ca}(\mathrm{v}) 12$, $\mathrm{Ca}(\mathrm{v}) 13$ and $\mathrm{Ca}(\mathrm{v}) 3$ 1. Eur. J. Pharmaco. 649, 263-267 http://dx.doi.org/10.1016/j.ejphar.2010.09.014

Traboulsie A., Chemin J., Chevalier M., Quignard J. F., Nargeot J., Lory P. (2007): Subunit-specific modulation of T-type calcium channels by zinc. J Physiol. 578, 159-171 http://dx.doi.org/10.1113/jphysiol.2006.114496

Triggle D. J. (2007): Calcium channel antagonists: clinical uses-past, present and future. Biochem. Pharmacol. 74, 1-9 http://dx.doi.org/10.1016/j.bcp.2007.01.016

Tsien R. W., Lipscombe D., Madison D. V., Bley K. R., Fox A. P. (1988): Multiple types of neuronal calcium channels and their selective modulation. Trends Neurosci. 11, 431-438 http://dx.doi.org/10.1016/0166-2236(88)90194-4

Wakamori M., Strobeck M., Niidome T., Teramoto T., Imoto K., Mori Y. (1998): Functional characterization of ion permeation pathway in the N-type $\mathrm{Ca}^{2+}$ channel. J. Neurophysiol. $79,622-634$

Watanabe K., Ochiai Y., Washizuka T., Inomata T., Miyakita Y., Shiba M., Izumi T., Shibata A., Qu Y. L., Nagatomo T. (1996): Clinical evaluation of serum amlodipine level in patients with angina pectoris. Gen. Pharmacol. 27, 205-209 http://dx.doi.org/10.1016/0306-3623(95)02022-5 
Wegener J. W., Nawrath H. (1995): Extracellular site of action of phenylalkylamines on L-type calcium current in rat ventricular myocytes. Naunyn Schmiedebergs Arch. Pharmacol. 352, $322-330$ http://dx.doi.org/10.1007/BF00168564

Williams M. E., Washburn M. S., Hans M., Urrutia A., Brust P. F., Prodanovich P., Harpold M. M., Stauderman K. A. (1999): Structure and functional characterization of a novel human low-voltage activated calcium channel. J. Neurochem. 72, 791-799 http://dx.doi.org/10.1046/j.1471-4159.1999.0720791.x

Zhou L. X., Finley D. K., Hassell A. E., Holtzman J. L. (1995): Pharmacokinetic interaction between isradipine and lovastatin in normal, female and male volunteers. J. Pharmacol. Exp. Ther. 273, 121-127

Received: September 16, 2011

Final version accepted: October 20, 2011 